\title{
Tumor markers in heart failure
}

\author{
Nicolae BACALBASA ${ }^{1}$, Alexandra GIREADA ${ }^{2}$, Irina BALESCU ${ }^{3}$, Cristian BALALAU $^{4}$, Mihai DIMITRIU ${ }^{1}$ \\ 1"Carol Davila" University of Medicine and Pharmacy, Bucharest \\ 2"Carol Davila" Central Military Emergency Hospital, Bucharest \\ 3"Ponderas" Hospital, Bucharest \\ 4"Sf. Pantelimon" Emergency Hospital, Bucharest
}

\begin{abstract}
It has been widely demonstrated that patients diagnosed with chronic heart failure present high levels of circulating neurohormones and inflammation markers which can secondarily induce an increase of the level of tumor markers such as CA 125, AFP, CEA, CA 15.3 or CA 19-9. This is a literature review regarding the benefits of determination of tumor markers serum levels in cases presenting chronic heart failure.
\end{abstract}

Keywords: chronic heart failure, CA 125, CA 15.3, CEA

\section{INTRODUCTION}

Literature data show that patients diagnosed with chronic heart failure often have elevated serum levels of neurohormones (norepinephrine and atrial natriuretic peptides), inflammation markers and cytokines (tumor necrosis factor and interleukin-6). (1-5)

The presence of cytokines in cardiac failure can explain the increase of CA 125 values, since it was reported that cytokines can stimulate the production and the release of CA 125 and other tumor markers from the cancer cells. (6-8)

Another possible explanation for the increase in CA 125 concentrations is represented by its production by the mesothelial cells, a production explained by a subclinical, mild accumulation of fluid or by the tissue stretching due to heart enlargement or congestion. (9)

\section{Variations of serum tumor marker concentrations in chronic heart failure}

A study realized in 2003 by P. Faggiano et al included 191 patients diagnosed with mild to severe chronic heart failure (left ventricular systolic dysfunction). It was well known that this kind of patients usually have elevated CA 125 values and the authors measured also the concentrations of serum AFP, CEA, CA 19.9, CA 15.3 and CA 125 . The results showed that only the levels of CA 125 exceeded the normal range. The mean CA 125 values $60 \mathrm{UI} / \mathrm{ml}$ in patients diagnosed with NYHA III class, $192 \mathrm{UI} / \mathrm{ml}$ in patients diagnosed with NYHA IV class and $16 \mathrm{UI} /$ $\mathrm{ml}$ in patients diagnosed with NYHA class I and II. The CA 125 levels significantly decreased with treatment and significantly correlated with the serum concentrations of BNP. (9) 
A study realized in 2004 by Varol E. et al included 44 patients diagnosed with heart failure and 30 healthy individuals. The authors measured the levels of CA 125, CA 15-3, CA 19-9, CEA and AFP in the two groups by means of the chemiluminescent enzyme immunoassay method. In the first group, the mean CA 125 concentration was $81.9 \mathrm{U} / \mathrm{ml}$ and the mean CA 19-9 concentration was $16.8 \mathrm{U} / \mathrm{ml}$. In the group of healthy individuals, the mean CA 125 concentration was $7.5 \mathrm{U} / \mathrm{ml}$ and the mean CA 19-9 concentration was $4.5 \mathrm{U} / \mathrm{ml}$. The CA 125 values corresponding to different NYHA classes were 17.7 $\mathrm{U} / \mathrm{ml}$ for the class $\mathrm{I} / \mathrm{II}, 99.6 \mathrm{U} / \mathrm{ml}$ for class III and $136.4 \mathrm{U} / \mathrm{ml}$ for class IV. The patients diagnosed with pericardial effusions had significantly higher serum CA 125 concentrations than the patients without pericardial effusions. (10)

\section{The influence of concurrent malignancies on serum levels of tumor markers}

The influence of different malignancies, of the kidney, liver or circulatory disturbances on the plasma concentrations of CA 125 is the subject of a study realized in 1999 by $\mathrm{H}$. Nägele et al. It included 118 patients pre- and 74 patients post heart transplantation. They measured the preand postoperative concentrations of CA 125, CEA, CA 19-9, CA 72-4, TPA, TPS and CYFRA 21-1 in order to find if there were occult neoplasms which could represent contraindications or sequels of heart transplantation. The cut-off values used for these markers were: $35 \mathrm{U} / \mathrm{ml}$ for CA 125 , $35 \mathrm{U} / \mathrm{ml}$ for CA 19-9, $5 \mathrm{ng} / \mathrm{ml}$ for CEA, $6.7 \mathrm{U} / \mathrm{ml}$ for CA 72-4, 95 U/I for TPA, 80 U/I for TPS, $3.3 \mathrm{ng} /$ $\mathrm{ml}$ for CYFRA 21-1. The concentrations of CA 125 and TPS increased with the NYHA stage: 29.4, 63, 174, $491 \mathrm{U} / \mathrm{ml}$ for CA 125 and 64, 118, 163 and $181 \mathrm{U} / \mathrm{ml}$ for TPS. The levels of CA 125 correlated with the right atrial pressure and with the pulmonary capillary wedge pressure. The results showed an association between poor graft function and the serum concentrations of CA 125 $(113 \mathrm{U} / \mathrm{ml})$, CA $72-4(8.4 \mathrm{U} / \mathrm{ml})$, and TPS $(154 \mathrm{U} / \mathrm{ml})$. It was found a correlation between the levels of CYFRA 21-1 and renal function. The levels of CEA, CA 19-9 and CYFRA 21-1 were not influenced by the degree of cardiac congestion. (11)

\section{The influence of cytokines on serum levels of tumor markers}

A study realized in 2006 by F. Kosar et al tried to find if there was any relationship between the serum concentrations of cytokines and the levels of tumor markers in patients diagnosed with heart failure. It included 35 patients and 33 normal controls. The authors measured the concentrations of the following cytokine levels: TNF- $\alpha$, IL-1 $\beta, I L-6$, and IL-10 using the ELISA method and the concentrations of the following tumor markers: CA 125, CA 19-9, CA 15-3, CEA and AFP using the chemiluminescent enzyme immunoassay. The results showed that the patients diagnosed with heart failure differentiated from the normal controls by means of significantly increased serum levels of TNF- $\alpha$, IL-6, IL-10, CA 125 and CA 19-9. The group of patients diagnosed with severe heart failure differentiated from the patients with mild heart failure by means of significantly increased serum levels of TNF- $\alpha$, IL- 6 , IL-10 and CA 125. The results showed an important correlation between the CA 125 values and the TNF- $\alpha$ values. The authors concluded that there is an association between this tumor marker and the cytokine system. (12)

A study realized in 2013 by Durak-Nalbantic A. et al included 76 patients and 26 normal individuals. The patients were divided into two groups: one with compensated patients and one with decompensated patients. The authors measured the serum concentrations of CA 125 and BNP. The mean CA 125 concentration in heart failure patients was higher than that found in normal subjects: $71.05 \mathrm{U} / \mathrm{ml}$ versus $10.75 \mathrm{U} / \mathrm{ml}$. Decompensated patients had higher CA 125 values than compensated patients: $94.9 \mathrm{U} / \mathrm{ml}$ versus $11.9 \mathrm{U} / \mathrm{ml}$. In the decompensated group, the patients which presented with pleural effusions had significantly higher CA 125 concentrations than the patients without pleural effusions: $205.1 \mathrm{U} / \mathrm{ml}$ versus $71.5 \mathrm{U} / \mathrm{ml}$. The mean CA 125 concentration in patients presenting with atrial fibrillation is $98.4 \mathrm{U} / \mathrm{ml}$ and the mean CA 125 concentration in patients not presenting with atrial fibrillation was $47.3 \mathrm{U} / \mathrm{ml}$. The patients presenting with enlarged left atrium had the same CA 125 concentration as the patients presenting with normal atrium size. There was a positive correlation between the serum levels of CA 125 and BNP. (13)

\section{CONCLUSIONS}

Research data demonstrates that CA 125 is increased in patients diagnosed with heart failure, that its serum levels are correlated with the degree of severity of the cardiac failure, reflected by the hemodynamic and echocardiographic parameters, that it can be used for estimating the prognosis of the disease and for guiding the clinical decisions. (14) 


\section{REFERENCES}

1. Francis G.S., Cohn J.N., Johnson G., Rector T.S., Goldman S., Simon A. Plasma norepinephrine, plasma renin activity, and congestive heart failure. Relations to survival and the effects of therapy in V-HeFT II. The V-HeFT VA Cooperative Studies Group. Circulation 1993; 87:VI40-VI48.

2. Cheng V., Kazanagra R., Garcia A., Lenert L., Krishnaswamy P., Gardetto N. Clopton P., Maisel A. A rapid bedside test for B-type peptide predicts treatment outcomes in patients admitted for decompensated heart failure: a pilot study. J Am Coll Cardiol 2001; 37:386-391.

3. Sharma R., Rauchhaus M., Ponikowski P.P., Varney S., Poole-Wilson P.A., Mann D.L., Coats A.J., Anker S.D. The relationship of the erythrocyte sedimentation rate to inflammatory cytokines and survival in patients with chronic heart failure treated with angiotensin-converting enzyme inhibitors. J Am Coll Cardiol 2000; 36:523-528.

4. Ferrari R., Bachetti T., Confortini R., Opasich C., Febo O., Corti A., Cassani G., Visioli O. Tumor necrosis factor soluble receptors in patients with various degrees of congestive heart failure. Circulation 1995; 92:1479-1486.

5. MacGowan G.A., Mann D.L., Kormos R.L., Feldman A.M., Murali S. Circulating interleukin-6 in severe heart failure. Am J Cardiol 1997; 79:1128-1131.

6. Zeimet A.G., Offner F.A., Marth C., Heim K., Feichtinger H., Daxenbichler G., Dapunt O. Modulation of CA-125 release by inflammatory cytokines in human peritoneal mesothelial and ovarian cancer cells. Anticancer Res 1997; 17:3129-3131.

7. Kubonishi I., Bandobashi K., Murata N., Daibata M., Ido E., Sonobe H., Ohtsuki Y., Miyoshi I. High serum levels of CA125 and interleukin-6 in a patient with Ki-1 lymphoma. Br J Haematol 1997; 98:450-452.

8. Marth C., Zeimet A.G., Widschwendter M., Daxenbichler G. Regulation of CA 125 expression in cultured human carcinoma cells. Int J Biol Markers 1998; 13:207-209.

9. Faggiano P., D'Aloia A., Brentana L., Bignotti T., Fiorina C., Vizzardi E., Dei C.L. Serum levels of different tumour markers in patients with chronic heart failure. Eur J Heart Fail 2005; 7:57-61.

10. Varol E., Ozaydin M., Dogan A., Kosarc F. Tumour marker levels in patients with chronic heart failure. Eur J Heart Fail 2005; 7:840-843.

11. Nagele H., Bahlo M., Klapdor R., Rodiger W. Fluctuations of tumor markers in heart failure patients pre and post heart transplantation. Anticancer Res 1999; 19:2531-2534.

12. Kosar F., Aksoy Y., Ozguntekin G., Ozerol I., Varol E. Relationship between cytokines and tumour markers in patients with chronic heart failure. Eur J Heart Fail 2006; 8:270-274.

13. Durak-Nalbantic A., Resic N., Kulic M., Pecar E., Zvizdic F., Dzubur A., Dilic M., Gojak R., Sokolovic S., Hodzic E., Brdjanovic S. Serum level of tumor marker carbohydrate antigen-CA125 in heart failure. Med Arch 2013; 67:241-244.

14. Vizzardi E., D'Aloia A., Curnis A., Dei C.L. Carbohydrate antigen 125: a new biomarker in heart failure. Cardiol Rev 2013; 21:23-26.

Vizitați site-ul revistei

Practica MEdicAlă pm.medica.ro 